\title{
ANALYSIS OF RELATIONS BETWEEN CROP TEMPERATURE INDICES AND YIELD OF DIFFERENT SUNFLOWER HYBRIDS FOLIAR TREATED BY BIOPREPARATIONS
}

\author{
MAREK KOVÁR*, IVAN ČERNÝ, DÁVID ERNST
}

Slovak University of Agriculture in Nitra, Slovak Republic

KOVÁR, M. - ČERNÝ, I. - ERNST, D: Analysis of relations between crop temperature indices and yield of different sunflower hybrids foliar treated by biopreparations. Agriculture (Pol'nohospodárstvo), vol. 62, 2016, no. 1, pp. 28-40.

\begin{abstract}
The application of biological active preparations (BAPs) and remote-sensing control in the management of agronomic intervention are an important part of successful crop cultivation. The effects of foliar application of two BAPs (containing amino acids or Abiestins $\mathrm{s}^{\circledR}$ ) on yield and yield-forming, as well eco-physiological traits calculated from infrared thermographs data (crop water stress index, CWSI and index of stomatal conductance, Ig) of three hybrids of sunflower were studied in field poly-factorial experiments, realised during two years (2012 and 2013). The results showed that the application of selected BAPs has contributed to an increase of the sunflower yield, in particular through an increase in the weight of thousand seeds $(r p=0.761, P<0.001)$. Similarly, oil content in achenes was significantly higher in treatments with BAPs, mainly with preparation containing free amino acids. The study describes the quantitative relationship between yield and quality of sunflower production $(r p=-0.41, P<0.01)$. Selected hybrids of sunflower in two growth stages showed the significant differences in CWSI and Ig (both at $P<0.01$ ), respectively. An analysis of negative linear relation between the yield of achenes and CWSI $(r p=-0.654, P<0.001)$ confirmed that higher value of plant stress resulted in a smaller yield and vice-versa. The opposite trend was observed between yield and Ig index $(r p=0.576, P<0.001)$. The data obtained from IR thermography can be used for monitoring the physiological health of sunflower plants, as well in potential prediction and control of yield.
\end{abstract}

Key words: infrared thermography, CWSI, yield, oil content, foliar preparations, sunflower

Sunflower currently is the world's fourth most important oil crop with a harvested area of about 25 million hectares in which 36 million tons of achenes are produced on average. France is the largest producer in EU countries, with a production of around 1.6 million tons. The production in Slovakia is around 0.2 million tons. The average world production of sunflower is $1.42 \mathrm{t} / \mathrm{ha}$ approximately. The crop area, yield and overall production of sunflower have been relatively stable in Slovakia in the past five years. The sunflower-cultivated area was 0.084 million hectares, the yield reached $2.3 \mathrm{t} / \mathrm{ha}$ and the total production reached 0.196 million tons in Slovakia in 2013 (FAO 2013). Complete and homogeneous stands provide high yield while respecting limiting factors of productivity (Pasda \& Diepenbrock 1991; Zheljazkov et al. 2008). The limiting factors of productivity of sunflower mainly are soil and habitat conditions - geographic location, altitude, soil quality and its properties (Helmy \& Ramadan 2009), climate and weather conditions - temperature, precipitation, year (Wanjari et al. 2001), the ability of plants - photosynthetic activity, respiration, transpiration, size of assimilation system, the genetic basis of the hybrid, resistance to adverse factor and creation and reduction of yield

Ing. Marek Kovár, PhD. (*Corresponding author), Department of Plant Physiology, FAFR - SUA Nitra, 94976 Nitra, Tr. A. Hlinku 2, Slovak Republic. E-mail: marek.kovar@uniag.sk

doc. Ing. Ivan Černý, PhD., Department of Plant Production, FAFR - SUA Nitra, 94976 Nitra, Tr. A. Hlinku 2, Slovak Republic. E-mail: ivan.cerny@uniag.sk

Ing. Dávid Ernst, Department of Plant Production, FAFR - SUA Nitra, 94976 Nitra, Tr. A. Hlinku 2, Slovak Republic 
forming elements (Gibbs 2004; Dalai et al. 2008) and agricultural engineering and farming methods - crop rotation, forecrop, soil cultivation, seed treatment, sowing rate, nutrition and fertilisation, application of biologically active substances, sowing, protection against diseases and pests and the quality of the harvest (Marschner 2003; Cerkal et al. 2011; Elezovic et al. 2012).

The agricultural practice that is successfully employed to eliminate the negative effects of stressful situation on crop productivity is the application of biologically active preparations (BAPs) (Calvo et al. 2014). Is well documented the positive effect of foliar application of BAPs with amino acids as an active substance on yield of many crops (Tejada \& Gonzales 2003; Jablonskyte-Rašče et al. 2013), including sunflower (Rauf 2008; Mátyás et al. 2014). It has been observed that application of BAPs stimulate photosynthetic performance and anti-oxidative defence metabolism, in addition to water, light and mineral use efficiency, as well uptake of mineral nutrition. Finally, these plant responses minimise the negative effects of environmental stresses on crop productivity (Rhodes et al. 1999; Oosterhuis \& Robertson 2000; Djanaguiraman et al. 2004; Kovár \& Černý 2012).

One approach that finds application in the management of the irrigation system, as well the screening of biological material and optimisation of agronomic intervention, is the measure of the temperature of leaf / crop (Jones et al. 2009). These approaches use thermometers in contact with the leaves, or (especially today) spot imaging and infrared cameras. The temperature of the sheet resulting from the plant and the power balance of the soil and the atmospheric conditions change transpiration, which is controlled by diffusion of water vapour through the vents, and thus stomatal conductivity $\left(\mathrm{g}_{\mathrm{S}}\right)$. The basic idea is that closure of stomata (decrease in $g_{s}$ ), which occurs under the conditions of stress, resulting in the reduction of heat energy dissipation and the temperature rise in the leaf lamina. Infrared (IR) thermography of plant leaf / crop is a good tool for assessment the stomatal conductivity, and the detection of water stress plants, efficient use of water management and irrigation (Jones 1999; Jones et al. 2009). Calculation of stress indices, which are based on measurements of leaf temperature / vegetation, is widespread in practice. The most common indices used in field conditions are: stress degree days index (SDD), temperature differential ( $\Delta T$, the temperature difference between leaf and air), the crop water stress index (CWSI), water deficit index (WDI) and the stomatal conductivity index (Ig) (Reginato 1983; Jones et al. 2009; Padhi et al. 2012). Several studies from past decades have been used the CWSI index to describe the water status of the crop grown at field (Idso et al. 1981; Jackson et al. 1981; O'Shaughnessy et al. 2011; Argyrokastritis et al. 2015). Taghvaeian et al. (2014) shows that CWSI index can be used for effective monitoring of water stress and scheduling irrigation in sunflower. This study concluded that CWSI strongly correlated with canopy growth intensity. The increase of CWSI value under crop water stress results in yield reduction. Previously, Gardner et al. (1981) and Irmak et al. (2000) correlated grain yields of corn with differences in canopy temperature and CWSI, respectively. The polynomial relationship between CWSI and both yield and protein content in soybean seeds was reported (Candogan et al. 2013).

Currently, no study is available on the effect of exogenous application of BAPs on stomatal activity calculated from IR thermography of sunflower plants and their relationship to yield of the seed. Therefore, the objectives of this study were to evaluate the effect of foliar application of selected biologically active preparations on yield, yield-forming parameters and oil content in seeds of sunflower, as well to determine the relationship between yield and CWSI and Ig indices calculated from IR thermography in two different growth stages of sunflower plants.

\section{MATERIAL AND METHODS}

\section{Plant material and treatments}

This experiment was conducted in order to investigate the effects of year-round weather conditions, biological material (genotype) and treatment by foliar preparations (containing the free amino acids or Abiestins ${ }^{\circledR}$ ) on selected yield-forming elements, yield and oil content in sunflower. The experiment was performed during 2012 and 2013 at the research fields of the Plant Biology and Ecol- 
ogy Centre, the Faculty of Agrobiology and Food Resources of the Slovak University of Agriculture (SUA) in Nitra, Slovakia $\left(48^{\circ} 19^{\prime} 25.41^{\prime \prime} \mathrm{N}\right.$ and $18^{\circ} 09^{\prime} 2.87^{\prime \prime} \mathrm{E}$, altitude $250 \mathrm{~m}$ above sea level). The experimental area is situated in the maize-growing region (climatic region: warm; climatic sub-region: mild dry or dry; climatic zone: warm and dry, with mild winter and long sunshine) and soil is, according to FAO classification, silt loam Haplic Luvisol (WRB 2006; Šimanský \& Kováčik 2015). The experiments were established by block method with a completely randomised design of experimental field plot trial $\left(60 \mathrm{~m}^{2}\right.$ per one plot $)$ in three repetitions. Forecrop of sunflower (Helianthus annuus L.) in seven-plot crop rotation was winter wheat (Triticum aestivum L.). Soil cultivation (stubble ploughing, autumn deep ploughing) and method of crop stand establishment (alternate row distance $0.70 \mathrm{~m}$, distance in row $0.22 \mathrm{~m}$ ) were performed in accordance with the principles of conventional technology of sunflower cultivation. The soil fertilisation was derived from soil agrochemical analysis for an expected yield of $3.0 \mathrm{t} / \mathrm{ha}$. The plants were fertilised (i) in 2012 with nitrogen at the rate of $107 \mathrm{~kg} / \mathrm{ha}$ urea, followed by $50 \mathrm{~kg} / \mathrm{ha}$ single superphosphate and of 200 $\mathrm{kg} / \mathrm{ha} \mathrm{KCl}$ and (ii) in 2013 at the rate of $200 \mathrm{~kg} / \mathrm{ha}$ DASA $^{\circledR}$ 26/13, using fertiliser applicator FERTI (FPM Agromehanica, Boljevac, Serbia). Fertilisers containing $\mathrm{P}$ and $\mathrm{K}$ were applied to the soil during autumn with deep ploughing. Fertilisers containing $\mathrm{N}$ were applied to the soil during pre-sow ploughing in the spring. Climatic characteristics of the experimental area were obtained from the Meteorological Station of Horticulture and Landscape Engineering Faculty of Slovak University of Agriculture in Nitra (Figure 1).

Three hybrids of sunflower, NK Brio, NK Neoma and NK Ferti, were used in the experiment. Three variants were established as (i) control; (ii) variant with application of preparation containing the amino acid $[9.3 \%$ of L- $\alpha$ amino acids (Asp, Ser, Glu, Gly, His, Arg, Thr, Ala, Pro, Cis, Tyr, Val, Met, Lys, Ile, Leu, Phe, Trp) and $2.1 \%$ of N, as well as $0.07 \%$ of zinc, $0.04 \%$ of manganase and $0.02 \%$ of boron] with trade name Terra-Sorb ${ }^{\circledR}$ Foliar (Biobérica S.A., Barcelona, Spain) and (iii) application of preparation containing the biologically active substances (Abiestins ${ }^{\circledR}$, minimal content $40 \mathrm{~g} / \mathrm{L}$ ) from near polar plants with trade name Unicum ${ }^{\circledR}$ (Ekoland Europe s.r.o., Praha, Czech Republic). The control variant was without foliar preparations. Preparations were applied manually with pressurised hand sprayer (capacity 10 L) Gamma10 (Mythos Di Martino, Mussolente, Italy) twice during the growing season at the following rates: (a) application of Terra-Sorb ${ }^{\circledR}$ Foliar was done in two stages (first at 2-4 leaf stage and second 20 days after the first application), both in dose of $1.5 \mathrm{~L} / \mathrm{ha}$; b) application of Unicum ${ }^{\circledR}$ was done in two stages (first at 2-4 leaf stage and second during flowering), both in the dose of $200 \mathrm{~mL} / \mathrm{ha}$.
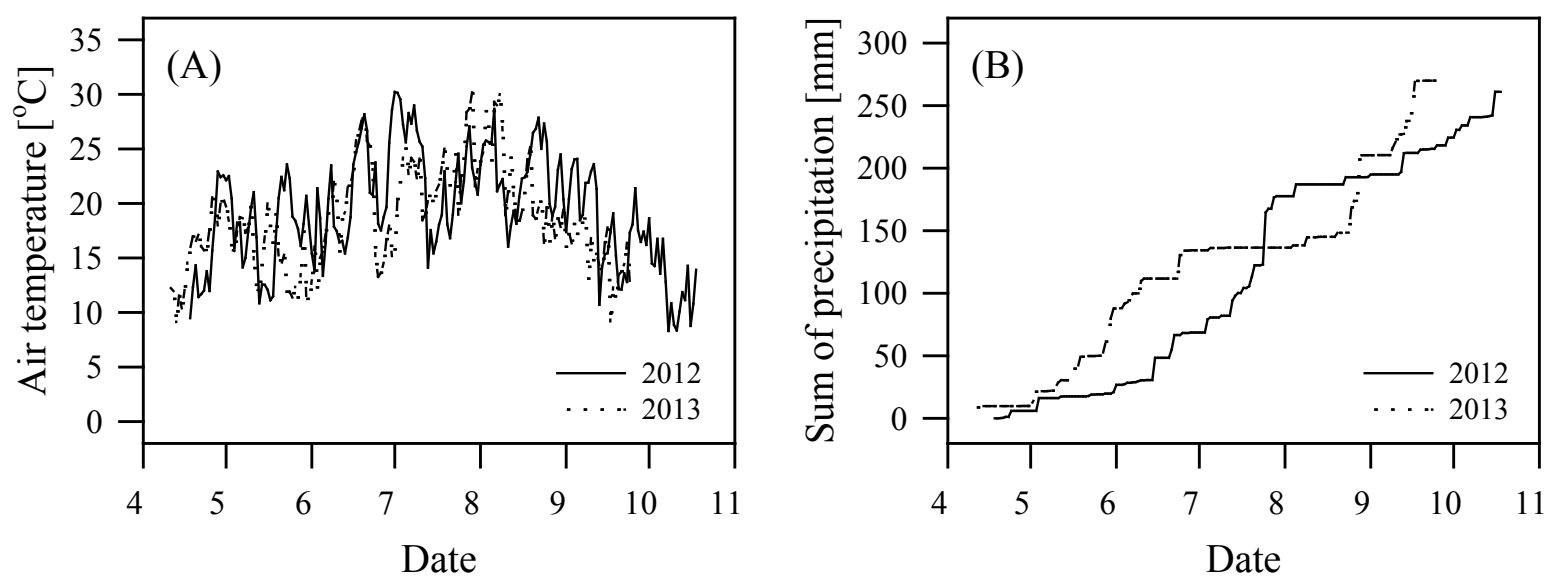

Figure 1. Mean daily air temperature (A) and sum of daily precipitation (B) during growth seasons of sunflower in 2012 (full line) and 2013 (dash line) 
Calculation of yield-forming parameters and oil content measurement

Heads were harvested manually and taken to the laboratory, where yield-forming elements were determined. The harvest was performed by small-plot combine CLAAS (CLAAS GmbH \& Co. KGaA, Harsewinkel, Germany). The yield of achenes harvested from experimental area was re-calculated to unit tonnes per hectare $[\mathrm{t} / \mathrm{ha}]$. Oil content in seed was determined by a standard method using the Soxhlet apparatus (Shahidi 2005). Prior to extraction, the seeds were mechanically crushed using a laboratory homogeniser to an average particle size of $1 \mathrm{~mm}$. The direct oil extraction was performed using petroleum ether reagent at $60^{\circ} \mathrm{C}$. Total extraction time during the analysis was 60 minutes $(15 \mathrm{~min}$ direct extraction samples immersed in the extraction reagent and 45 min exposure to reagent vapours). After extraction, the crude oil was directly weighed and oil content was recalculated in the sample.

\section{Calculation of CWSI and Ig indices}

Measurement of leaf temperature $\left(T^{\text {leaf }}\right)$ was carried out in two different stages under plant development, flowering and ripening (BBCH 63 and 87) by hand IR thermal camera EasIR-4 (Bibus AG, Fehraltorf, Switzerland). Thermal images were taken from mature leaves of 10 plants which underwent experimental treatment, between 11:00 and 13:00 hours SCER from a distance $2.0 \mathrm{~m}$ perpendicular to the lamina surface and at an elevation of $1.5 \mathrm{~m}$. IR thermal camera uses uncooled FBA detector with $160 \times$ 120 pixel elements, sensitive in the spectral range of $8-14 \mu \mathrm{m}$ and angular field of view of $20.6 \times 15.5^{\circ}$, with an accuracy $\pm 2.0^{\circ} \mathrm{C}$ and thermal resolution $\leq 0.1{ }^{\circ} \mathrm{C}$. Emissivity was set at 0.95 . Two references were used for measured minimal and maximal surface temperature. Crop imaging was taken from the continuous thermal images from two references surfaces. The wet and dry artificial surface of green colour was used to measure the minimal $\left(T^{\mathrm{wet}}\right)$ and maximal $\left(T^{\text {dry }}\right)$ temperature. Thermal images were analysed with Guide IR Analyser (Bibus AG, Fehraltorf, Switzerland). Two lines were crossed over lamina and average leaf temperature $\left(\mathrm{T}^{\text {leaf }}\right)$ was determined. Crop water stress index (CWSI) and stomatal conductance index (Ig) were calculated from the following equations:

$$
\begin{aligned}
\text { CWSI } & =\frac{\left(T^{\text {leaf }}-T^{\text {wet }}\right)}{\left(T^{\text {dry }}-T^{\text {wet }}\right)} \\
I g & =\frac{\left(T^{\text {dry }}-T^{\text {leaf }}\right)}{\left(T^{\text {leaf }}-T^{\text {wet }}\right)}
\end{aligned}
$$

\section{Statistical analysis}

The experimental data were graphically assessed as mean values for each experimental member with the corresponding standard deviation. Statistical analysis was performed using Statistica software, version 10 (StatSoft, Inc., Tulsa, Oklahoma, USA). The normal distribution and homogeneity of experimental results was tested by Kolmogorov-Smirnov and Lavene's test. Statistical differences between the individual experimental members (genotype, treatment, and year) were analysed by multi-factorial ANOVA analysis and homogenous groups were identified using Duncan's post-hoc test at a significance level of $P<0.05$. The correlation analysis between experimental traits was expressed by the Pearson correlation coefficient $\left(r_{p}\right)$.

\section{RESULTS AND DISCUSSION}

\section{Yield-forming parameters}

Yield forming elements (head diameter, weight of head and weight of thousand achenes) were influenced by genotypes, treatments, year-round weather conditions and by its combined effect (Table 1, 2). The results of combined ANOVA showed high significant influence of year-round weather conditions on head diameter, weight of head and weight of thousand achenes (Table 2). This phenomenon has been reported by other researches (Amjed et al. 2011; Rauf et al. 2012; Mátyás et al. 2014). The results confirmed course of year-round weather conditions. Experimental years were unbalanced and very different. In view of the observed average monthly temperatures, as compared to the longterm climate normal, both years can be considered as above average. In terms of precipitation during the growing season for both experimental years, it was typical of an unequal course (Figure 1). Amjed et al. (2011) and Mátyás et al. (2014) observed that head diameter was high influenced by genotypes. Černý et al. (2013) found significant influence of genotype on weight of head. Rondanini et al. (2003) 
$\mathrm{T}$ a

Production and physiological traits of three sunflower genotypes treated with two bio-preparations during the seasons of 2012 and 2013. Data represents the mean \pm standard deviation.

\begin{tabular}{|c|c|c|c|c|c|c|c|}
\hline Genotype & Treatment & Year & $\begin{array}{l}\text { Head diameter } \\
{[\mathrm{mm}]}\end{array}$ & $\begin{array}{l}\text { Weight of head } \\
{[\mathrm{g}]}\end{array}$ & TWA & Yield [t/ha] & Oil content [\%] \\
\hline \multirow{6}{*}{ NK Brio } & \multirow{2}{*}{ Untreated } & 2012 & $186.7 \pm 20.8^{\mathrm{aA}}$ & $260.5 \pm 38.5^{\mathrm{bB}+}$ & $59.16 \pm 0.21^{\mathrm{cB}^{+}}$ & $2.17 \pm 0.08^{\mathrm{aA}+}$ & $51.20 \pm 1.91^{\mathrm{aA}+}$ \\
\hline & & 2013 & $200.3 \pm 2.5^{\mathrm{cA}}$ & $170.1 \pm 2.0^{\mathrm{cC}+}$ & $34.60 \pm 0.83^{\mathrm{abB}+}$ & $1.84 \pm 0.05^{\mathrm{aC}+}$ & $61.84 \pm 0.50^{\mathrm{bC}+}$ \\
\hline & \multirow{2}{*}{ Terra-Sorb } & 2012 & $186.7 \pm 15.3^{\mathrm{aA}}$ & $242.5 \pm 24.5^{\mathrm{bAB}+}$ & $63.20 \pm 0.14^{\mathrm{cA}^{+}}$ & $3.35 \pm 0.18^{\mathrm{aB}+}$ & $50.19 \pm 0.43^{\mathrm{aB}^{+}}$ \\
\hline & & 2013 & $186.0 \pm 2.0^{\mathrm{cA}}$ & $118.4 \pm 2.5^{\mathrm{cA}^{+}}$ & $29.23 \pm 2.00^{\mathrm{abA}+}$ & $2.08 \pm 0.10^{\mathrm{aB}^{+}}$ & $58.47 \pm 0.50^{\mathrm{bA}+}$ \\
\hline & \multirow{2}{*}{ Unicum } & 2012 & $180.0 \pm 20.0^{\mathrm{aA}^{+}}$ & $180.4 \pm 34.8^{\mathrm{bA}+}$ & $64.68 \pm 0.44^{\mathrm{cC}+}$ & $2.70 \pm 0.44^{\mathrm{aB}+}$ & $54.36 \pm 0.55^{\mathrm{aB}^{+}}$ \\
\hline & & 2013 & $230.3 \pm 1.5^{\mathrm{cB}^{\mathrm{B}}}$ & $133.1 \pm 3.0^{\mathrm{cB}+}$ & $25.36 \pm 2.00^{\mathrm{abA}+}$ & $1.06 \pm 0.04^{\mathrm{aA}^{+}}$ & $58.67 \pm 0.50^{\mathrm{bB}+}$ \\
\hline \multirow{6}{*}{$\begin{array}{l}\text { NK } \\
\text { Neoma }\end{array}$} & \multirow{2}{*}{ Untreated } & 2012 & $173.3 \pm 15.3^{\mathrm{aA}+}$ & $207.1 \pm 14.6^{\mathrm{aB}+}$ & $54.03 \pm 0.11^{\mathrm{aB}+}$ & $2.62 \pm 0.07^{\mathrm{aA}+}$ & $52.31 \pm 1.71^{\mathrm{bA}+}$ \\
\hline & & 2013 & $192.0 \pm 2.0^{\mathrm{cA}+}$ & $127.3 \pm 2.2^{\mathrm{bC}+}$ & $39.05 \pm 4.92^{\mathrm{bB}+}$ & $2.78 \pm 0.02^{\mathrm{bC}+}$ & $52.25 \pm 0.60^{\mathrm{aC}+}$ \\
\hline & \multirow{2}{*}{ Terra-Sorb } & 2012 & $200.0 \pm 20.0^{\mathrm{aA}}$ & $164.6 \pm 31.1^{\mathrm{aAB}+}$ & $48.80 \pm 0.19^{\mathrm{aA}^{+}}$ & $2.35 \pm 0.11^{\mathrm{aB}+}$ & $55.79 \pm 0.47^{\mathrm{bB}+}$ \\
\hline & & 2013 & $195.3 \pm 4.0^{\mathrm{cA}}$ & $116.2 \pm 2.0^{\mathrm{bA}+}$ & $26.93 \pm 0.90^{\mathrm{bA}+}$ & $1.49 \pm 0.04^{\mathrm{bB}+}$ & $52.75 \pm 0.53^{\mathrm{aA}^{+}}$ \\
\hline & \multirow{2}{*}{ Unicum } & 2012 & $180.0 \pm 20.0^{\mathrm{aA}}$ & $174.9 \pm 19.4^{\mathrm{aA}+}$ & $64.32 \pm 0.17^{\mathrm{aC}+}$ & $3.13 \pm 0.37^{\mathrm{aB}+}$ & $56.70 \pm 0.46^{\mathrm{bB}+}$ \\
\hline & & 2013 & $190.0 \pm 2.0^{\mathrm{cB}}$ & $131.6 \pm 1.4^{\mathrm{bB}+}$ & $28.63 \pm 0.36^{\mathrm{bA}+}$ & $1.54 \pm 0.03^{\mathrm{bA}+}$ & $56.45 \pm 0.55^{\mathrm{aB}^{\mathrm{B}}}$ \\
\hline \multirow{6}{*}{ NK Ferti } & \multirow{2}{*}{ Untreated } & 2012 & $166.7 \pm 5.77^{\mathrm{aA}}$ & $170.3 \pm 17.5^{\mathrm{aB}+}$ & $58.23 \pm 0.13^{\mathrm{bB}+}$ & $2.49 \pm 0.08^{\mathrm{aA}+}$ & $49.76 \pm 1.53^{\mathrm{aA}+}$ \\
\hline & & 2013 & $184.0 \pm 2.0^{\mathrm{aA}}$ & $108.5 \pm 1.9^{\mathrm{aC}+}$ & $26.44 \pm 0.33^{\mathrm{aB}+}$ & $2.29 \pm 0.02^{\mathrm{cC}+}$ & $55.72 \pm 0.47^{\mathrm{aC}+}$ \\
\hline & \multirow{2}{*}{ Terra-Sorb } & 2012 & $175.0 \pm 5.0^{\mathrm{aA}+}$ & $210.3 \pm 10.0^{\mathrm{aAB}+}$ & $56.16 \pm 0.17^{\mathrm{bA}^{+}}$ & $2.91 \pm 0.22^{\mathrm{aB}^{+}}$ & $54.62 \pm 0.40^{\mathrm{aB}^{+}}$ \\
\hline & & 2013 & $190.0 \pm 2.0^{\mathrm{aA}+}$ & $119.2 \pm 1.9^{\mathrm{aA}+}$ & $28.41 \pm 0.41^{\mathrm{aA}+}$ & $2.11 \pm 0.02^{\mathrm{cB}+}$ & $54.06 \pm 0.38^{\mathrm{aA}+}$ \\
\hline & \multirow{2}{*}{ Unicum } & 2012 & $176.7 \pm 17.6^{\mathrm{aA}+}$ & $189.9 \pm 13.7^{\mathrm{aA}^{+}}$ & $55.60 \pm 0.15^{\mathrm{bC}+}$ & $2.45 \pm 0.20^{\mathrm{aB}+}$ & $50.18 \pm 0.47^{\mathrm{aB}+}$ \\
\hline & & 2013 & $194.0 \pm 2.0^{\mathrm{aB}+}$ & $130.4 \pm 2.2^{\mathrm{aB}+}$ & $31.62 \pm 0.38^{\mathrm{aA}+}$ & $1.95 \pm 0.02^{\mathrm{cA}^{+}}$ & $52.76 \pm 0.38^{\mathrm{aB}+}$ \\
\hline
\end{tabular}

Table 1 continued

\begin{tabular}{|c|c|c|c|c|c|c|}
\hline Genotype & Treatment & Year & CWSI-4 & CWSI-6 & Ig-4 & Ig-6 \\
\hline \multirow{6}{*}{ NK Brio } & \multirow{2}{*}{ Untreated } & 2012 & $0.50 \pm 0.02^{\mathrm{aB}}$ & $0.40 \pm 0.01^{\mathrm{aA}^{+}}$ & $1.00 \pm 0.08^{\mathrm{aA}}$ & $0.72 \pm 0.00^{\mathrm{bC}+}$ \\
\hline & & 2013 & $0.47 \pm 0.02^{\mathrm{aB}}$ & $0.86 \pm 0.12^{\mathrm{bA}+}$ & $1.09 \pm 0.06^{\mathrm{bA}}$ & $0.39 \pm 0.05^{\mathrm{aA}^{+}}$ \\
\hline & \multirow{2}{*}{ Terra-Sorb } & 2012 & $0.42 \pm 0.03^{\mathrm{aA}+^{+}}$ & $0.31 \pm 0.05^{\mathrm{aA}+^{+}}$ & $1.23 \pm 0.05^{\mathrm{aA}}$ & $0.74 \pm 0.02^{\mathrm{bA}^{+}}$ \\
\hline & & 2013 & $0.39 \pm 0.00^{\mathrm{aA}+}$ & $0.79 \pm 0.23^{\mathrm{bAB}+}$ & $1.21 \pm 0.01^{\mathrm{bA}}$ & $0.38 \pm 0.05^{\mathrm{aB}+}$ \\
\hline & \multirow{2}{*}{ Unicum } & 2012 & $0.56 \pm 0.06^{\mathrm{aA}+}$ & $0.72 \pm 0.03^{\mathrm{aA}+}$ & $0.90 \pm 0.16^{\mathrm{aB}^{+}}$ & $0.58 \pm 0.01^{\mathrm{bB}+}$ \\
\hline & & 2013 & $0.50 \pm 0.01^{\mathrm{aA}^{+}}$ & $0.99 \pm 0.07^{\mathrm{bB}+}$ & $0.73 \pm 0.04^{\mathrm{bA}+}$ & $0.42 \pm 0.03^{\mathrm{aA}+}$ \\
\hline \multirow{6}{*}{$\begin{array}{l}\text { NK } \\
\text { Neoma }\end{array}$} & \multirow{2}{*}{ Untreated } & 2012 & $0.53 \pm 0.03^{\mathrm{aB}}$ & $0.79 \pm 0.03^{\mathrm{cA}+}$ & $0.88 \pm 0.09^{\mathrm{aA}}$ & $0.56 \pm 0.01^{\mathrm{aC}+}$ \\
\hline & & 2013 & $0.54 \pm 0.05^{\text {ьв }}$ & $0.73 \pm 0.04^{\mathrm{aA}^{+}}$ & $0.93 \pm 0.12^{\mathrm{aA}}$ & $0.42 \pm 0.03^{\mathrm{bA}+}$ \\
\hline & \multirow{2}{*}{ Terra-Sorb } & 2012 & $0.61 \pm 0.04^{\mathrm{aA}}$ & $0.88 \pm 0.03^{\mathrm{cA}}$ & $0.79 \pm 0.07^{\mathrm{aA}^{+}}$ & $0.47 \pm 0.00^{\mathrm{aA}+}$ \\
\hline & & 2013 & $0.60 \pm 0.01^{\mathrm{bA}}$ & $0.81 \pm 0.13^{\mathrm{aAB}}$ & $0.66 \pm 0.02^{\mathrm{aA}+}$ & $0.36 \pm 0.03^{\mathrm{bB}+}$ \\
\hline & \multirow{2}{*}{ Unicum } & 2012 & $0.34 \pm 0.00^{\mathrm{aA}^{+}}$ & $0.55 \pm 0.04^{\mathrm{cA}^{+}}$ & $1.42 \pm 0.08^{\mathrm{aB}+}$ & $0.60 \pm 0.02^{\mathrm{aB}+}$ \\
\hline & & 2013 & $0.49 \pm 0.01^{\mathrm{bA}+}$ & $0.91 \pm 0.10^{\mathrm{aB}^{+}}$ & $1.01 \pm 0.05^{\mathrm{aA}+}$ & $0.48 \pm 0.02^{\mathrm{bA}+}$ \\
\hline \multirow{6}{*}{ NK Ferti } & \multirow{2}{*}{ Untreated } & 2012 & $0.52 \pm 0.00^{\mathrm{bB}+}$ & $0.49 \pm 0.03^{\mathrm{abA}+}$ & $0.92 \pm 0.01^{\mathrm{aA}^{+}}$ & $0.67 \pm 0.02^{\mathrm{aC}+}$ \\
\hline & & 2013 & $0.59 \pm 0.02^{\mathrm{bB}+}$ & $0.82 \pm 0.13^{\mathrm{abA}+}$ & $0.78 \pm 0.06^{\mathrm{aA}+}$ & $0.37 \pm 0.05^{\mathrm{bA}+}$ \\
\hline & \multirow{2}{*}{ Terra-Sorb } & 2012 & $0.31 \pm 0.04^{\mathrm{bA}+}$ & $0.71 \pm 0.19^{\mathrm{bA}}$ & $0.96 \pm 0.11^{\mathrm{aA}}$ & $0.44 \pm 0.04^{\mathrm{aA}^{+}}$ \\
\hline & & 2013 & $0.53 \pm 0.02^{\mathrm{bA}^{+}}$ & $0.74 \pm 0.10^{\mathrm{abAB}}$ & $0.89 \pm 0.07^{\mathrm{aA}}$ & $0.38 \pm 0.02^{\mathrm{bB}+}$ \\
\hline & \multirow{2}{*}{ Unicum } & 2012 & $0.42 \pm 0.01^{\mathrm{bA}+}$ & $0.60 \pm 0.05^{\mathrm{bA}+}$ & $1.26 \pm 0.11^{\mathrm{aB}}$ & $0.57 \pm 0.04^{\mathrm{aB}+}$ \\
\hline & & 2013 & $0.47 \pm 0.03^{\mathrm{bA}+}$ & $0.77 \pm 0.07^{\mathrm{abB}+}$ & $1.10 \pm 0.12^{\mathrm{aA}}$ & $0.50 \pm 0.02^{\mathrm{bA}+}$ \\
\hline
\end{tabular}

Note: Small and large letters indicate significant differences (Duncan's test, $\alpha=0.05$ ) between genotypes and treatments, respectively. ${ }^{+}$Indicates significant differences between seasons.

TWA - weight of thousand achenes; CWSI - crop water stress index; Ig - stomatal conductance index; numbers

-4 and -6 are measurements during vegetation period 
observed that average weight of achenes is the decisive yield-forming factor that plays an important role in assessing the production potential of the sunflower hybrids. In this study, the significant influence of treatment on head diameter was not reported (Table 2), which probably results from water deficit in soil, mainly in 2013. It is well documented that drought-induced inhibition of growth is general response of plant to water deficit (Baldini et al. 1997; Rauf 2008; Jones et al. 2009). On the other hand, Kheybari et al. (2013) found the significant effect of foliar-applied amino acids on head diameter. We found significant influence of the treatment on weight of head and weight of thousand achenes (Table 2). The results of this study about the effect of applying different preparations on sunflower agree well with Hussain et al. (2012) and Mátyás et al. (2014). The combined effect of genotype $\times$ treatments had significant influence on head diameter. The weight of head and weight of thousand achenes were influenced highly significantly (Table 2). Mátyás et al. (2014) described non-significant influence of this interaction on head diameter and weight of head but high significant effect on weight of thousand achenes. The combined effect of genotype $\times$ year had not significant influence on head diameter. This result confirmed state of Mátyás et al. (2014). In weight of head and weight of thousand achenes, we found high a significant influence of this interaction (Table 2). Chimenti et al. (2001) reported that the production process of sunflower is a result of the properties of the parental lines of hybrids, course of weather conditions and its interaction, which agree with our findings. The combined effects of treatments $\times$ year had significant influence on head diameter and weight of head. The weight of thousand achenes was influenced highly significantly (Table 2). This observation agrees with the results of Mátyás et al. (2014). The interaction of genotypes $\times$ treatments $\times$ year did not have a significant effect on the head diameter and weight of head but it had a high significant influence on the weight of thousand achenes.

T

Analysis of variance in production and physiological traits of sunflower genotypes treated with two biopreparations during the seasons of 2012 and 2013

\begin{tabular}{|l|c|c|r|r|r|r|r|r|r|r|}
\hline & & $\begin{array}{c}\text { Head } \\
\text { diameter } \\
{[\mathrm{mm}]}\end{array}$ & $\begin{array}{c}\text { Weight } \\
\text { of head } \\
{[\mathrm{g}]}\end{array}$ & TWA & $\begin{array}{c}\text { Yield } \\
{[\mathrm{t} / \mathrm{ha}]}\end{array}$ & $\begin{array}{r}\text { Oil } \\
\text { content } \\
{[\%]}\end{array}$ & CWSI-4 & CWSI-6 & Ig-4 & Ig-6 \\
\hline Genotypes & F & 5.970 & 17.708 & 27.220 & 4.810 & 56.400 & 17.970 & 1.733 & 4.004 & 12.940 \\
$(\mathrm{G})$ & $P$ & 0.006 & 0.000 & 0.000 & 0.014 & 0.000 & 0.000 & 0.191 & 0.027 & 0.000 \\
\hline Treatments & F & 2.140 & 4.637 & 28.560 & 12.17 & 6.600 & 25.410 & 6.119 & 13.849 & 51.240 \\
$(\mathrm{~T})$ & $P$ & 0.133 & 0.016 & 0.000 & 0.000 & 0.004 & 0.000 & 0.005 & 0.000 & 0.000 \\
\hline \multirow{2}{*}{ Year $(\mathrm{Y})$} & $\mathrm{F}$ & 23.040 & 228.110 & 5584.23 & 301.570 & 187.600 & 30.370 & 47.972 & 22.234 & 349.430 \\
& $P$ & 0.000 & 0.000 & 0.000 & 0.000 & 0.000 & 0.000 & 0.000 & 0.000 & 0.000 \\
$\mathrm{G} \times \mathrm{T}$ & $\mathrm{F}$ & 2.880 & 9.809 & 28.820 & 35.820 & 32.700 & 60.540 & 8.290 & 50.873 & 26.600 \\
& $P$ & 0.036 & 0.000 & 0.000 & 0.000 & 0.000 & 0.000 & 0.000 & 0.000 & 0.000 \\
\hline $\mathrm{G} \times \mathrm{Y}$ & $\mathrm{F}$ & 1.400 & 3.355 & 41.85 & 13.890 & 129.000 & 37.430 & 19.291 & 2.729 & 71.990 \\
& $P$ & 0.240 & 0.046 & 0.000 & 0.000 & 0.000 & 0.000 & 0.000 & 0.078 & 0.000 \\
\hline $\mathrm{T} \times \mathrm{Y}$ & $\mathrm{F}$ & 3.930 & 5.640 & 49.910 & 56.600 & 29.300 & 3.350 & 1.854 & 10.433 & 5.280 \\
& $P$ & 0.029 & 0.007 & 0.000 & 0.000 & 0.000 & 0.046 & 0.171 & 0.000 & 0.010 \\
\hline $\mathrm{G} \times \mathrm{T} \times \mathrm{Y}$ & $\mathrm{F}$ & 2.500 & 2.553 & 46.100 & 7.980 & 11.100 & 14.650 & 10.026 & 2.664 & 34.110 \\
& $P$ & 0.060 & 0.056 & 0.000 & 0.000 & 0.000 & 0.000 & 0.000 & 0.048 & 0.000 \\
\hline
\end{tabular}

Note: greyscale of cells indicates significant differences at level $<0.05$ (light-grey), $<0.01$ (medium-grey) and $<0.001$ (dark-grey). TWA - weight of thousand achenes; CWSI - crop water stress index; Ig - stomatal conductance index; numbers -4 and -6 are measurements during vegetation period 


\section{Yield and oil content in achenes}

The yield of sunflower was more favourable in 2012 when the achieved yield was higher in comparison with 2013 (Table 1). The results of combined ANOVA showed high significant influence of year weather conditions on the yield of sunflower achenes (Table 2). The results agree well with other researches (Pereyra-Irujo \& Aguirrezábal 2007; Mátyás et al. 2014), who confirmed high significant influence of year-round weather conditions on the yield of sunflower achenes. After evaluation of impact of hybrids on the yield, we found that the highest yield was achieved in 2013 with the NK Neoma hybrid, and the lowest in 2013 with NK Brio hybrid (Table 1). The impact of genotype on the yield of achenes was highly significant (Table 2). The results agree with the observations of Bakhat et al. (2006), Ibrahim (2012) and Mátyás et al. (2014) who confirmed a significant influence of genotype on yield of sunflower achenes. After influence assessment of foliar preparations on the yield, we found that the highest yield was in variant with Terra-Sorb ${ }^{\circledR}$ Foliar preparation application in 2012 with NK Brio hybrid (Table 1). This finding does not confirm to Mátyás et al. (2014) who recorded higher yield in control variant. The lowest yield was found in variant with Unicum ${ }^{\circledR}$ preparation application in 2013 with NK Brio hybrid (Table 1). In our experiments, we found high significant influence of treatment on the yield of achenes (Table 2). The achieved results agree well with Černý \& Veverková (2012) who stated that the impact of foliar preparations on yield of sunflower achenes was significant. On the basis of experimental results, we consider the foliar application of preparations on stands of sunflower as appropriate rationalization tool of its cultivation. In the experiment, we found a a positive correlation between the yield of achenes and the weight of head and weight of thousands achenes. As weight of head and weight of thousand achenes increases, the yield of achenes also increases (Table 3). Mátyás et al. (2014) found positive correlation between yield of achenes and weight of thousand achenes, but negative correlation between yield of achenes and weight of head. With the average of head, we found the negative correlation. With the increase in the head diameter was observed a decrease in the yield of achenes (Table 3). The achieved results are contrary to the studies of Beg and Aslam (1984) and Ali et al. (2007) who reported positive impact of head diameter on yield of achenes. We assume that this phenomenon could be influenced by two factors: first, we assumed that achenes were filled poorly, or second, it is possible that large inter-space occurred

T a b 1 e 3

Correlation coefficients for production and physiological traits in three sunflower genotypes treated with two biopreparations during the seasons of 2012 and 2013

\begin{tabular}{|c|c|c|c|c|c|c|c|c|c|}
\hline Traits & $\begin{array}{c}\text { Head } \\
\text { diameter }\end{array}$ & $\begin{array}{l}\text { Weight of } \\
\text { head }\end{array}$ & TAW & Yield & $\begin{array}{c}\text { Oil } \\
\text { content }\end{array}$ & CWSI-4 & CWSI-6 & Ig-4 & Ig-6 \\
\hline Head diameter & 1 & & & & & & & & \\
\hline Weight of head & $-0.158^{\mathrm{NS}}$ & 1 & & & & & & & \\
\hline TAW & $-0.485^{+++}$ & $0.788^{+++}$ & 1 & & & & & & \\
\hline Yield & $-0.502^{+++}$ & $0.522^{+++}$ & $0.761^{+++}$ & 1 & & & & & \\
\hline Oil content & $0.444^{+++}$ & $-0.365^{++}$ & $-0.467^{+++}$ & $-0.411^{++}$ & 1 & & & & \\
\hline CWSI-4 & $0.145^{\mathrm{NS}}$ & $-0.346^{+}$ & $-0.311^{+}$ & $-0.365^{++}$ & $-0.119^{\mathrm{NS}}$ & 1 & & & \\
\hline CWSI-6 & $0.349^{++}$ & $-0.534^{+++}$ & $-0.617^{+++}$ & $-0.654^{+++}$ & $0.602^{+++}$ & $0.247^{\mathrm{NS}}$ & 1 & & \\
\hline $\operatorname{Ig}-4$ & $-0.208^{\mathrm{NS}}$ & $0.343^{+}$ & $0.388^{++}$ & $0.483^{+++}$ & $-0.015^{\mathrm{NS}}$ & $-0.762^{+++}$ & $-0.440^{+++}$ & 1 & \\
\hline Ig-6 & $-0.313^{+}$ & $0.631^{+++}$ & $0.742^{+++}$ & $0.576^{+++}$ & $-0.632^{+++}$ & $-0.117^{\mathrm{NS}}$ & $-0.786^{+++}$ & $0.360^{++}$ & 1 \\
\hline
\end{tabular}

Note: Grey scale indicates ${ }^{\mathrm{NS}}$ - not significant difference (white cell) $,{ }^{+},{ }^{++}$and ${ }^{+++}$significant differences at level $<0.05$ (light-grey), $<0.01$ (medium-grey) and $<0.001$ (dark-grey cell)

TWA - weight of thousand achenes; CWSI - crop water stress index; Ig - stomatal conductance index; numbers -4 and -6 are measurements during vegetation period 
among the seeds. Less likely is the third possibility that it may be a combination of the two possible factors. The combined effect of genotype $\times$ treatment on yield of achenes was highly significant (Table 2). Mátyás et al. (2014) described significant influence of this combine effect on yield of achenes, which agrees well with our observations. The combined effects of genotype $\times$ year, treatment $\times$ year and genotype $\times$ treatment $\times$ year had a high significant impact on the yield of achenes (Table 2).

We found that 2013 was more favourable for oil content than 2012 (Table 1). The results of the combined ANOVA showed that unbalanced course of weather conditions had high a significant influence on oil content in sunflower achenes (Table 2). The significant influence of year-round weather conditions on oil content of sunflower achenes was described by Pereyra-Irujo and Aguirrezábal (2007) and Echarte et al. (2013). The assessment of genotype impact on oil content showed that the highest oil content was achieved in 2013 with the NK Brio hybrid, the lowest in 2012 with the NK Ferti hybrid (Table 1). The impact of genotype on oil content was highly significant (Table 2). Pereyra-Irujo and Aguirrezábal (2007), Gesch and Johnson (2013) and Yasin et al. (2013) claimed that sunflower hybrids

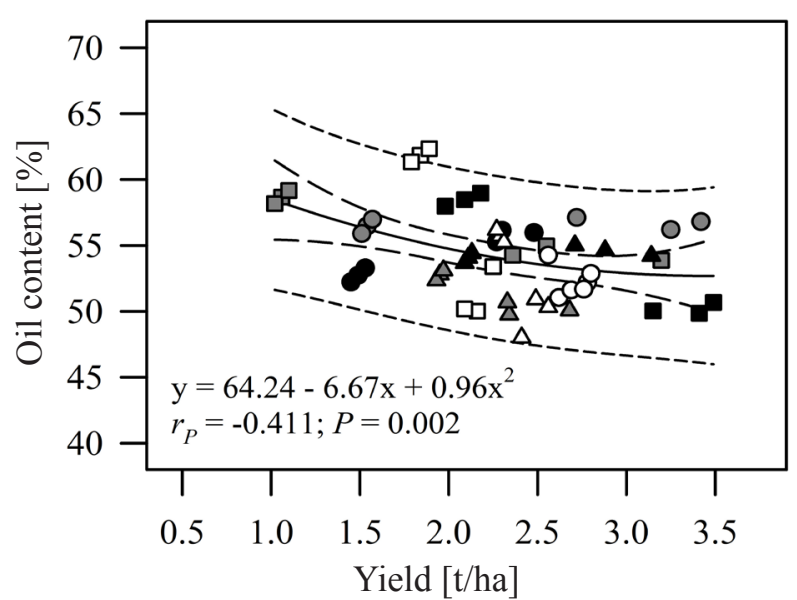

Figure 2. The relationship between yield of achenes [ $\mathrm{t} / \mathrm{ha}$ ] and oil content [\%] in three sunflower genotypes. The relationship represented two growing seasons and application of bio-preparations.

Symbols: NK Brio - square; NK Neoma - circle; NK Ferti - triangle; untreated plants - white; Terra-Sorb ${ }^{\circledR}$ Foliar - black; Unicum ${ }^{\circledR}$ - gray. Solid line shows polynomial quadratic regression, long-dash line shows $95 \%$ confidence band and short-dash line $95 \%$ prediction band. shows differences in the oil content, which correspond with our findings. The results of combined ANOVA showed that the impact of treatment on oil content was highly significant (Table 2). Our results agree well with Černý and Veverková (2012), who found a significant influence of foliar preparations on oil content of sunflower achenes. In relation to the fat content, a positive correlation was found with the head diameter. The higher head diameter also increased the fat content of achenes (Table 3). In our experiments, oil content had a negative correlation to the weight of head, weight of thousand achenes and the yield. With decreasing weight of head value, weight of thousands achenes and the yield of achenes, the oil content increased (Table 3). The results do not confirm of the findings of Mátyás et al. (2014) who found a positive correlation of oil content with the weight of thousand achenes and yield of achenes. The quantitative relationship between sunflower yield and quality of production $\left(r_{p}=-0.41, P<0.01\right)$ is shown in Figure 2. However, the head diameter and weight of head has negative correlation, as reported by the author. All combined effects $(\mathrm{G} \times \mathrm{T}, \mathrm{G} \times \mathrm{Y}, \mathrm{T} \times \mathrm{Y}$ and $\mathrm{G} \times \mathrm{T} \times \mathrm{Y})$ had high significant impact on oil content (Table 2 ).

\section{Temperature indices}

Sunflower productivity and oil content in achenes are strongly affected by the availability of soil water (Reddy et al. 2003; Rauf 2008) although sunflower plants are commonly regarded as drought-tolerant (Baldini et al. 1997). Nevertheless, many studies showed that water deficit decreased the production performance of sunflower. The yield reduction of sunflower by water shortage depends on the growth stage of the plant as well genetically determined resistance and stress severity (Langeroodi et al. 2014). The most critical period for water availability is reproductive stages of flowering and achenes filling (Karam et al. 2007; Rauf 2008). This is the main reason why we evaluated the water status during two different stages of sunflower ontogeny using infrared thermography. The reduction in the rate of transpiration, caused by inhibition of stomatal opening under drought condition, causes an increase of the crop surface temperature. The leaf surface with intensive transpiration is characterised by a lower temperature than the surrounding environment. 
In agro-biological research, as well as in practical agronomy applications, the most widespread expression of these differences is the calculation of the temperature difference $\left(\Delta T=T^{\text {leaf }}-T^{\text {air }}\right)$. Because $\Delta T$ (in many studies referred as canopy temperature depression [CTD]) is directly influenced by many physiological processes of plants, it is a good indicator of biological fitness genotype in a given environment.

In our study, the temperature indices were calculated in two principal yield-forming stages for sun- flower (flowering and ripening). Sunflower hybrids differed significantly in crop water stress index (CWSI) and calculated stomatal conductance index (Ig) (Tables 1 and 2). The mean value of crop water stress index (CWSI) was $0.59 \pm 0.19$ and significantly smaller at 2012, mainly in flowering (CWSI-4). The sum of precipitation in flowering period was 243.4 $\mathrm{mm}$ in 2012 and $154.2 \mathrm{~mm}$ in 2013, respectively. Then, the redistribution of precipitation in both years of growth period flowering and harvesting was very different. As shown in Figure 1, July and

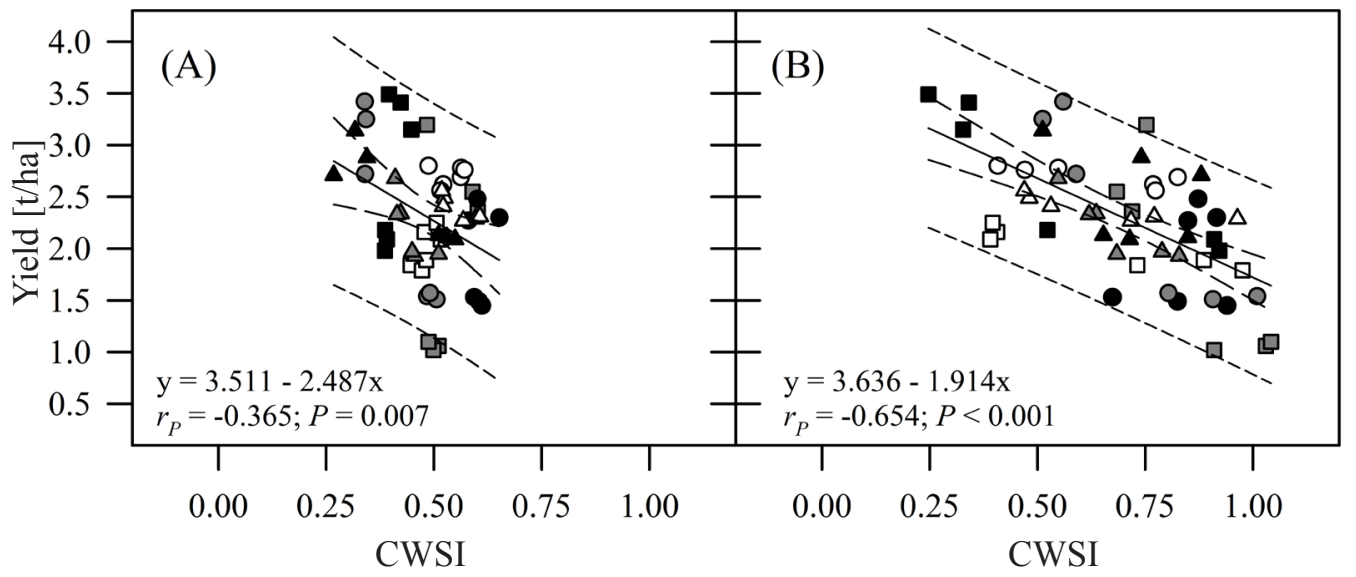

Figure 3. The relationships between yield of achenes [t/ha] and crop water stress index (CWSI) in three sunflower genotypes. CWSI was measured at BBCH 63 (A) and 87 (B). Relationships represented two growing seasons and application of bio-preparations. Symbols: NK Brio - square; NK Neoma - circle; NK Ferti - triangle; untreated plants - white; Terra-Sorb ${ }^{\circledR}$ Foliar - black; Unicum ${ }^{\circledR}$ - gray. Solid line shows linear quadratic regression, long-dash line shows $95 \%$ confidence band and short-dash line $95 \%$ prediction band.

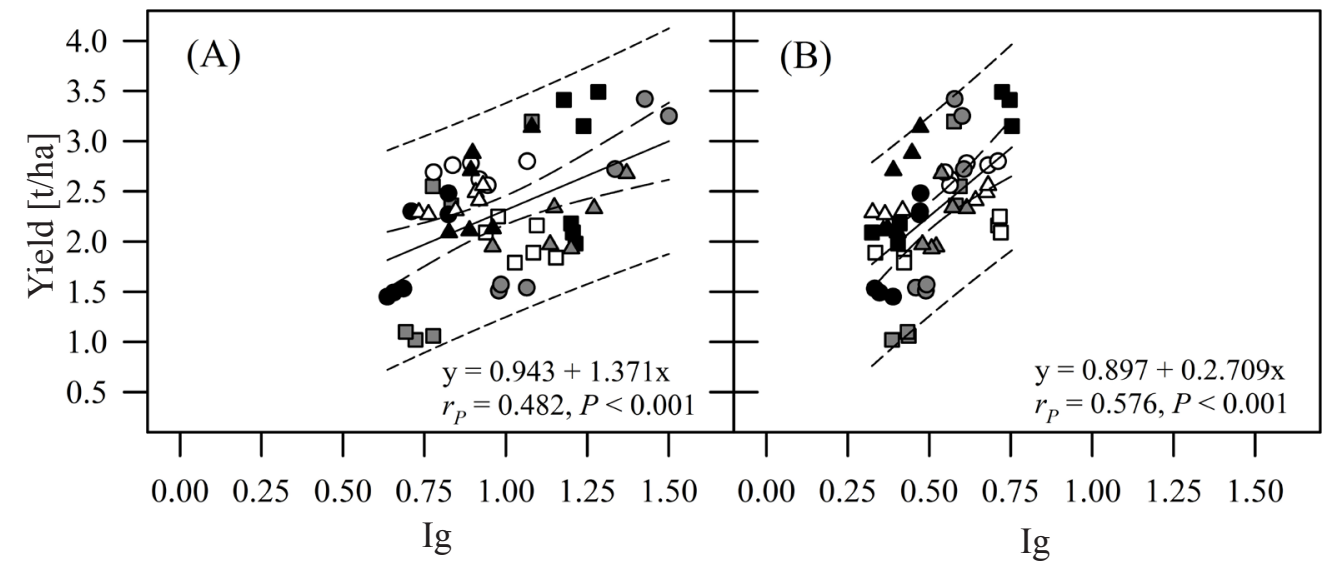

Figure 4. The relationships between yield of achenes [t/ha] and index of stomatal conductance (Ig) in three sunflower genotypes treated with biologically active substances. Ig was measured at $\mathrm{BBCH} 63$ (A) and 87 (B). Relationships represented two growing seasons and application of bio-preparations. Symbols: NK Brio - square; NK Neoma - circle; NK Ferti - triangle; untreated plants - white; Terra-Sorb ${ }^{\circledR}$ Foliar - black; Unicum ${ }^{\circledR}$ - gray. Solid line shows linear quadratic regression, long-dash line shows $95 \%$ confidence band and short-dash line $95 \%$ prediction band. 
August in 2013 was characterised by rainless period with higher average daily temperature, as compared with 2012. Thus, rainless period in 2013 reflects an increase of water deficit in plants and water stress as documented by the CWSI increase. During ripening of achenes (August and beginning in September 2012), the significant $(P<0.01)$ increase of CWSI was observed as a result of water deficit in both years. Table 1 shows that genotype NK Brio reached the lowest value of CWSI in both the experimental years, indicating that this genotype is more tolerant to drought than NK Neoma and NK Ferti. It was observed that foliar application of BAPs leads to a decrease of CWSI and therefore reduced water stress only in the earlier growth period. This prevention effect to water stress was evident using biopreparate Unicum ${ }^{\circledR}$. Despite strong dependency of temperature indices on environmental factors (soil and plant water content, air temperature and humidity, wind velocity; Jones 1999), the hybrid differences in overall mean levels of CWSI and Ig were on some occasions highly significant $(P<0.01)$. Genotypic differences were observed in many studies with various field crops (Fischer et al. 1998; Padhi et al. 2012; Zia et al. 2012), including sunflower (Nielsen \& Anderson 1989; Taghvaeian et al. 2014). The analysis of variance showed a significant effect $(P<0.001)$ of all combined effects $(\mathrm{G} \times \mathrm{T}, \mathrm{G} \times \mathrm{Y}$, $\mathrm{T} \times \mathrm{Y}$ and $\mathrm{G} \times \mathrm{T} \times \mathrm{Y}$ ) on CWSI and Ig indices measured in both growth stages of sunflower plants (except CWSI-6) (Table 2).

The relationship between temperature indices and achenes yield of sunflower hybrids are demonstrated in Figures 3 and 4. The linear regression analysis between CWSI and yield for each phase of ontogeny were explained by a $13 \%$ and $42 \%(P<0.01)$ of the variation in sunflower yield (Figure $3 \mathrm{~A}, 3 \mathrm{~B}$ ). The tighter negative relationship was found when measuring CWSI during ripening of the seed. In this growth stage, the filling of sunflower seeds is very sensitive to stress situation (Rauf 2008). The increase of stress intensity results in stomatal closuring and so CWSI increases. It was also observed (Taghvaeian et al. 2014) that CWSI measured for sunflower hybrid strongly correlated with fraction of intercept light and leaf area index and thus the plant growth. Similar results for sunflower were observed previously by Connor et al. (1985). In our study, the reduced seed filling activity under ripening led to a decline of TAW and this is documented by high correlation coefficient with CWSI-6 $\left(r_{p}=-0.65\right.$, $P<0.001$ ) (Figure 3).

The reciprocal parameter to CWSI, stomatal conductance index (Ig), is calculated. Jones (1999) showed the strong linear correlation between stomatal conductance and $\mathrm{I}_{4}$ index (also called as Ig), and we used this parameter for the determination of its relationship to yield of sunflower hybrids (Figure 4A, 4B). We found a strong $(P<0.001)$ positive correlation of Ig to yield $\left(r_{p}=0.48\right.$ and 0.57 for phase flowering and ripening, respectively). The maximal observed level of Ig was about 3.5, which agrees with detected maximal stomatal conductance measured for well-watered leaves of many plants (Jones 1999; Jones et al. 2009; Leinonen et al. 2006). With decreasing Ig value, a reduction in stomatal conductance is seen and thus occurrence of stressful situation resulted in yield limitation.

\section{CONCLUSIONS}

The present study shows that foliar applications of biologically active preparations (BAPs) positively influences the production performance as well oil content in seeds of selected sunflower hybrids at two meteorologically different years. The results showed that the application of selected BAPs significantly increased of sunflower yield, in particular through increase the weight of thousand seeds $\left(r_{p}=0.761\right.$, $P<0.001)$. Similarly, oil content in achenes was significantly higher in treatments with BAPs, mainly with the preparation containing free amino acids. Analysis of indices derived from infrared (IR) thermography confirmed that BAPs (containing mainly free amino acids) significantly reduced the sensitivity of stomata to stressful environmental situations (lower CWSI and higher Ig). Therefore, this response allows better plant water use and carbon storage under drought and temperature stresses, resulting in higher yield of achenes. Finally, the data obtained from IR thermography can be used for monitoring of physiological health of sunflower plants, as well in potential prediction and control of the yield. 
Acknowledgements. This research was supported by the Scientific Grant Agency of Ministry of Education, Science, Research and Sport of the Slovak Republic, project no. 1/0093/13.

\section{REFERENCES}

ALI, A. - TANVEER, A. - NADEEM, M.A. - TAHIR, M. - HUSSAIN, M. 2007. Effect of varying planting pattern on growth, achene yield and oil contents of sunflower (Helianthus annuus L.). In Pakistan Journal of Agricultural Sciences, vol. 44, pp. 449-452.

AMJED, A. - MUHAMMAD, A. - IJAZ, R. - SAFDAR, H. - MATLOB, A. 2011. Sunflower (Helianthus annuus L.) hybrids performance at different plant spacing under agro-ecological conditions of Sargodha, Pakistan. In International Conference on Food Engineering and Biotechnology IPCBEE, IACSIT Press, Singapore, vol. 9, pp. 317-322.

ARGYROKASTRITIS, I.G. - PAPASTYLIANOU, P.T. - ALEXANDRIS, S. 2015. Leaf water potential and crop water stress index variation for full and deficit irrigated cotton in Mediterranean conditions. In $\mathrm{Ag}$ riculture and Agricultural Science Procedia, vol. 4, pp. 463-470.

BAKHAT, J.S. - AHMAD, M. - TARIQ, H. - SHAFI, M. 2006. Performance of various hybrids of sunflower in Peshawar valley. In Journal of Agricultural and Biological Science, vol. 1, no. 3, pp. 25-29.

BALDINI, M. - VANNOZZI, G.P. - TURI, M. - GOMEZ-SACHEZ, D. 1997. Results of a physiological selection approach to improve drought resistance in sunflower. In Genetika a Šlechtění, vol. 33, no. 3, pp. 181-195.

BEG, A. - ASLAM, M. 1984. Sunflower production practices. In Progressive Farming, vol. 4, pp. 14-19.

CALVO, P. - NELSON, L. - KLOEPPER, J.W. 2014. Agricultural uses of plant biostimulants. In Plant and Soil, vol. 383, pp. 3-41. DOI: 10.1007/s11104-0142131-8

CANDOGAN, B.N. - SINCIK, M. - BUYUKCANGAZ, H. - DEMIRTAS, C. - GOKSOY, A.T. - YAZGAN, S. 2013. Yield, quality and crop water stress index relationships for deficit-irrigated soybean [Glycine $\max$ (L.) Merr.] in sub-humic climatic conditions. In Agricultural Water Management, vol. 118, no. 2, pp. 113-121. DOI: 10.1016/j.agwat.2012.11.021

CERKAL, R. - KAMLER, J. - ŠKARPA, P. - POKORNÝ, R. - MAREČEK, V. - FAJMAN, M. - MUŠKA F. 2011. Methods of cultivation and important factors affecting the yield and quality of sunflower. In HUGHES, V.G. (Ed) Sunflowers: Cultivation, Nutrition, and Biodiesel Uses. Brno : Department of Crop Science, Breeding and Plant Medicine, Faculty of Agronomy, Mendel University in Brno, pp. 47-98. ISBN 9781617613098

ČERNÝ, I. - VEVERKOVÁ, A. - MÁTYÁS, M. KOVÁR, M. 2013. Evaluation of year weather con- ditions and hybrids impact on the sunflower (Helianthus annuus, L.) achene yield and fat content. In Journal of Microbiology, Biotechnology and Food Sciences, vol. 2, pp. 1739-1747.

ČERNÝ, I. - VEVERKOVÁ, A. 2012. Production parameters of sunflower (Helianthus annuus, L.) influenced by weather conditions and foliar application of Pentakeep-V and Atonik. In Journal of Microbiology, Biotechnology and Food Sciences, vol. 1, no. 1, pp. 887-896.

CHIMENTI, C.A. - HALL, A.J. - LÓPEZ, M.S. 2001. Embryo-growth rate and duration in sunflower as affected by temperature. In Field Crops Research, vol. 69, pp. 81-88.

CONNOR, D.J. - JONES, T.R. - PALTA, J.A. 1985. Response of sunflower to strategies of irrigation I. Growth, yield and the efficiency of water use. In Field Crops Research, vol. 10, pp. 15-36. DOI: 10.1016/0378-4290(85)90003-6

DALAI, G.M. - SEN, S. - PAL, A.K. 2008. Water use and productivity of summer sunflower (Helianthus annuus L.) as influenced by irrigation and phosphorus. In Research on Crops, vol. 9, pp. 283-285.

DJANAGUIRAMAN, M. - DEVI, D.D. - SHANKER, A.K. - SHEEBA, J.A. - BANGARUSAMY, U. 2004. The role of nitrophenol on delaying abscission of tomato flowers and fruits. In Food, Agriculture and Environment, vol. 2, pp. 183-186.

ECHARTE, M.M. - PUNTEL, L.A. - AGUIRREZÁBAL, L.A.N. 2013. Assessment of the critical period for the effect of intercepted solar radiation on sunflower oil fatty acid composition. In Field Crops Research, vol. 149, pp. 213-222. DOI: 10.1016/j.fcr.2013.05.007

ELEZOVIC, I. - AVISHEK, D. - SAVA, V. - DJORDJE, G. - MILENA, S. - GORAN, M. - STEVAN, Z.K. 2012. Yield and yield components of imidazolinone-resistant sunflower (Helianthus annuus L.) by pre-emergence herbicide and time of post-emergence weed removal. In Field Crops Research, vol. 128, no. 3, pp. 137-146. DOI: 10.1016/j.fcr.2011.12.020

FAO, 2013. FAO Statistical Yearbook - World Food and Agriculture. Rome : Food and Agriculture Organization of the United Nations. 289 p. ISBN 978-92-5107396-4

FISCHER, R.A. - REES, D. - SAYRE, K.D. - LU, Z.-M. - CONDON, A.G. - SAAVEDRA, A.L. 1998. Wheat yield progress associated with higher stomatal conductance and photosynthetic rate and coller canopies. In Crop Science, vol. 38, no. 6, pp. 1467-1475. DOI: 10.2135/cropsci1998.0011183X003800060011x

GARDNER, B.R. - BLAD, B.L. - MAURER, R.E. WATTS, D.G. 1981. Relationship between crop temperature and the physiological and phenological development of differentially irrigated corn. In Agronomy Journal, vol. 73, no. 4, pp. 743-747. DOI: 10.2134/agronj 1981.00021962007300040042x

GESCH, R.W. - JOHNSON, B.L. 2013. Post-anthesis development of oil content and composition with respect to seed moisture in two high-oleic sunflower hybrids in the northern US. In Field Crops Research, vol. 148 , pp. 1-8. DOI: 10.1016/j.fcr.2013.03.019 
GIBBS, M. 2004. Effect of light intensity on the distribution of $\mathrm{C} 14$ in sunflower leaf metabolites during photosynthesis. In Archives of Biochemistry and Biophysics, vol. 45, no. 1, pp. 156-160.

HELMY, A.M. - RAMADAN, M.F. 2009. Agronomic performance and chemical response of sunflower (Helianthus annuus L.) to some organic nitrogen sources and conventional nitrogen fertilisers under sandy conditions. In Grasas y Aceites, vol. 60, pp. 55-67. DOI: $10.3989 /$ gya. 032508

HUSSAIN, S. - ALI, A. - IBRAHIM, M. - SALEEM, M.F. - BUKHSH, M.A.A.H.A. 2012. Exogenous application of abscisic acid for drought tolerance in sunflower (Helianthus annuus L.): a review. In Journal of Animal and Plant Sciences, vol. 22, no. 3, pp. 806-826.

IBRAHIM, H.M. 2012. Response of some sunflower hybrids to different levels of plant density. In $A P C B E E$ Procedia, vol. 4, pp. 175-182. DOI: $10.1016 / \mathrm{j}$.apcbee. 2012.11 .030

IDSO, S.B. - JACKSON, R.D. - PINTER, P.J. - REGINATO, R.J. - HATFIELD, J.L. 1981. Normalizing the stress-degree-day parameter for environmental variability. In Agricultural Meteorology, vol. 24, pp. 45-55. DOI: 10.1016/0002-1571(81)90032-7

IRMAK, S. - HAMAN, D.Z. - BASTUG, R. 2000. Determination of crop water stress index for irrigation timing and yield estimation of corn. In Agronomy Journal, vol. 92, no. 6, pp. 1221-1227. DOI: 10.2134/ agronj2000.9261221x

JABLONSKYTE-RAŠČE，D. - MAIKŠTENIENE，S. MAINKEVIČIENE, A. 2013. Evaluation of productivity and quality of common wheat (Triticum aestivum L.) and spelt (Triticum spelta L.) in relation to nutrition conditions. In Zemdirbyste-Agriculture, vol. 100, no. 1, pp. 45-56. DOI 10.13080/z-a.2013.100.007

JACKSON, R.D. - IDSO, S.D. - REGINATO, R.J. PINTER, P.J. 1981. Canopy temperature as a crop water stress indicator. In Water Resources Research, vol. 17, no. 4, pp. 1133-1138. DOI: 10.1029/ WR017i004p01133

JONES, H.G. - SERRAJ, R. - LOVEYS, B.R. - XIONG, L. - WHEATON, A. - PRICE, A.H. 2009. Thermal infrared imaging of crop canopies for the remote diagnosis and quantification of plant responses to water stress in field. In Functional Plant Biology, vol. 36, no. 11, pp. 978-989. DOI: 10.1071/FP09123

JONES, H.G. 1999. Use of infrared thermometry for estimation of stomatal conductance as a possible aid to irrigation scheduling. In Agricultural and forest meteorology, vol. 95, no. 4, pp. 139-149. DOI: $10.1016 /$ S0168-1923(99)00030-1

KARAM, F. - LAHOUD, R. - MASSAD, R. - KABALAN, R. - BREIDI, J. - CHALITA, C. - ROUPHAEL, Y. 2007. Evapotranspiration, seed yield and water use efficiency of drip irrigated sunflower under full and deficit irrigation conditions. In Agricultural $\mathrm{Wa}$ ter Management, vol. 90, no. 3, pp. 213-223. DOI: 10.1016/j.agwat.2007.03.009

KHEYBARI, M. - DANESHIAN, J. - RAHMANI, H.A. - SEYFZADEH, S. - KHIAVI, M. 2013. Response of sunflower head characteristics to PGPR and amino acid application under water stress conditions. In International Journal of Agronomy and Plant Production, vol. 4, no. 8, pp. 1760-1765.

KOVÁR, M. - ČERNÝ, I. 2012. Regulation of production performance of chicory plants by foliar application of biologically active substances. In Journal of Central European Agriculture, vol. 13, pp. 747-759. DOI: 10.5513/JCEA01/13.4.1124

LANGEROODI, A.R.S. - KAMKAR, B. - da SILVA, J.A.T. - ATAEI, M. 2014. Response of sunflower cultivars to deficit irrigation. In Helia, vol. 37, no. 60, pp. 37-58. DOI: 10.1515/helia-2014-0003

LEINONEN, I. - GRANT, O.M. - TAGLIAVIA, C.P.P. - CHAVES, M.M. - JONES, H.G. 2006. Estimating stomatal conductance with thermal imagery. In Plant, Cell and Environment, vol. 29, no. 8, pp. 1508-1518. DOI: $10.1111 /$ j.1365-3040.2006.01528.x

MARSCHNER, H. 2003. Mineral nutrition of Higher Plants. London : Academic Press Limited. ISBN 9780-12-384905-2

MÁTYÁS, M. - ČERNÝ, I. - KOVÁR, M. 2014. Sunflower (Helianthus annuus L.) yield-forming elements influenced by year weather conditions and application of biological preparations Terra - Sorb and Unicum. In Journal of Microbiology, Biotechnology and Food Sciences, vol. 3, pp. 131-133.

NIELSEN, D.C. - ANDERSON, R.L. 1989. Infrared thermometry to measure single leaf temperatures for quantification of water stress in sunflower. In Agronomy Journal, vol. 81, no. 5, pp. 840-842. DOI: 10.2134/agronj1989.00021962008100050028x

O'SHAUGHNESSY, S.A. - EVETT, S.R. - COLAIZZI, P.D. - HOWELL, T.A. 2011. Using radiation thermometry to evaluate crop water stress in soybean and cotton. In Agricultural Water Management, vol. 98, no. 10, pp. 1523-1535. DOI: $10.1016 / \mathrm{j} . \mathrm{ag}-$ wat.2011.05.005

OOSTERHUIS, D. - ROBERTSON, W.C. 2000. The use of plant growth regulators and other additives in cotton production. In AAES Special Report 198, Proceedings of the 2000 Cotton Research Meeting, pp. 22-32.

PADHI, J. - MISRA, R.K. - PAYERO, J.O. 2012. Estimation of soil water deficit in an irrigated cotton field with infrared thermography. In Field Crop Research, vol. 126, pp. 45-55. DOI: 10.1016/j.fcr.2011.09.015

PASDA, G. - DIEPENBROCK, W. 1991. The physiological yield analisys of sunflower (Helianthus annuus L.), agricultural factors and crop production. In Fett Wissenschaft Technologie - Fat Science Technology, vol. 93, pp. 235-243.

PEREYRA-IRUJO, G. - AGUIRREZÁBAL, L.A.N. 2007. Sunflower yield and quality interactions and variability: Analysis through a simple simulation model. In Agricultural Forest Meteorology, vol. 143, pp. 252265. DOI: $10.1016 / \mathrm{j}$.agrformet.2007.01.001

RAUF, A. - MAQSOOD, M. - AHMAD, A. - GONDAL, A.S. 2012. Yield and oil content of sunflower (Helianthus annuus L.) as influenced by spacing and reduced irrigation condition. In Journal of Crop Production, vol. 1, no. 1, pp. 41-45. 
RAUF, S. 2008. Breeding sunflower (Helianthus annuus L.) for drought tolerance. In Communications in Biometry and Crop Science, vol. 3, no. 1, pp. 29-44.

REDDY, G.K.M. - DANGI, K.S. - KUMAR, S.S. - REDDY, A.V. 2003. Effect of moisture stress on seed yield and quality in sunflower, Helianthus annuus L. In Journal of Oilseeds Research, vol. 20, no. 2, pp. 282-283.

REGINATO, R.J. 1983. Field quantification of crop water stress. In Transaction of the ASAE, vol. 26, no. 3, 772-775. DOI: 10.13031/2013.34021

RHODES, D. - VERSLUE, P.E. - SHARP, R.E. 1999 Role of amino acids in abiotic stress resistance. In SINGH, B.K. (Ed) Plant Amino Acids: Biochemistry and Biotechnology. New York : Marcel Dekker, pp. 319-356. ISBN 13:978-0824702045

RONDANINI, D. - SAVIN R. - HALL A. J. 2003. Dynamics of fruit growth and oil quality of sunflower (Helianthus annuus L.) exposed to brief intervals of high temperature during achene filling. In Field Crops Research, vol. 83, pp. 79-90.

SHAHIDI, F. 2005. Extraction and Measurement of Total Lipids. In WROLSTAD, R.E. et al. (Eds.) Handbook of Food Analytical Chemistry, Volume 1: Water, Proteins, Enzymes, Lipids, and Carbohydrates. Hoboken New Jersey : John Wiley \& Sons, Inc., pp. 425-436. ISBN 0-471-66378-6

ŠIMANSKÝ, V. - KOVÁČIK, P. 2015. Long-term effects of tillage and fertilization on $p H$ and sorption parameters of haplic Luvisol. In Journal of Elementology, vol. 20, pp. 1033-1040. DOI: $10.5601 / \mathrm{je}-$ lem.2015.20.1.857

TAGHVAEIAN, S. - COMAS, L. - DEJONGE, K.C. TROUT, T.J. 2014. Conventional and simplified canopy temperature indices predict water stress in sun- flower. In Agricultural Water Management, vol. 144, pp. 69-80. DOI: $10.1016 /$ j.agwat.2014.06.003

TEJADA, M. - GONZALES, J.L. 2003. Influence of foliar fertilization with amino acids and humic acids on productivity and quality of Asparagus. In Biological Agriculture and Horticulture, vol. 21, no. 3, pp. 277291. DOI: 10.1080/01448765.2003.9755270

WANJARI, R.H. - YADURAJU, N.T. - AHUJA, K.N. 2001. Critical period of crop-weed competition in rainy-season sunflower (Helianhus annuus). In Indian Journal of Agronomy, vol. 46, pp. 309-313.

YASIN, M. - MAHMOOD, A. - ALI, A. - AZIZ, M. - JAVAID, M.M. - IQBAL, Z. - TANVEER, A. 2013. Impact of varying planting patterns and fertiliser application strategies on autumn planted sunflower hybrid. In Cercetări Agronomice în Moldova, vol. 66, no. 2, pp. 39-51. DOI: 10.2478/v10298-012-0082-x

ZHELJAZKOV, V.D. - VICK, B.A. - EBELHAR, M.W. - BUEHRING, N. - BALDWIN, B. - ASTATKIE, T. - MILlER, J.F. 2008. Yield, oil content, and composition of sunflower (Helianthus annuus, L.) grown at multiple locations in Mississippi. In Agronomy Journal, vol. 100, no. 3, pp. 635-642. DOI: 10.2134/ agronj2007.0253

ZIA, S. - WENYONG, D. - SPREER, W. - SPOHRER, K. - YIONGKUI, H. - MÜLLER, J. 2012. Assessing crop water stress of winter wheat by thermography under different irrigation regimes in North China Plain. In International Journal of Agricultural and Biological Engineering, vol. 5, no. 3, pp. 24-34. DOI: $10.3965 / \mathrm{j}$. ijabe. 20120503.003

Received: November 23, 2015 